УДК 633.18:631.674.6:631.816.1

DOI https://doi.org/10.32848/agrar.innov.2021.10.2

\title{
УРОЖАЙНІСТЬ ТА ЯКІСТЬ ЗЕРНА РИСУ В УМОВАХ КРАПЛИННОГО ЗРОШЕННЯ ЗАЛЕЖНО ВІД ДОЗ МІНЕРАЛЬНИХ ДОБРИВ
}

\author{
ВОРОНюК 3.С. - кандидат сільськогосподарських наук, старший науковий співробітник \\ https://orcid.org/0000-0002-3109-0702 \\ Інститут рису Національної академії аграрних наук \\ ВОЖЕГОВ С.Г. - доктор сільськогосподарських наук, старший науковий співробітник \\ https://orcid.org/0000-0003-0877-2593 \\ Інститут рису Національної академії аграрних наук \\ TКАЧ M.C. - PhD (Агрономія) \\ https://orcid.org/0000-0002-7497-6423 \\ Інститут рису Національної академії аграрних наук \\ РОМЕНСЬКИЙ В.Ю. - науковий співробітник \\ https://orcid.org/0000-0002-1120-6376 \\ Інститут рису Національної академії аграрних наук
}

Постановка проблеми. Рис (Oryza sativa L.) є одним із найпоширеніших представників родини злакових у світовій культурі землеробства. Крупа цього злаку основний продукт харчування більш як 3 млрд мешканців нашої планети. Рис вирощують у 118 країнах світу між $49^{\circ}$ північної та $35^{\circ}$ південної широти. Щорічно цією культурою засівається близько 160 млн. га, з яких отримують понад 740 млн т рису при середній урожайності зерна до 4,5 т/ га.

Обсяг споживання крупи рису в Україні становить 110-115 тис. т, що на 20-25\% менше встановлених міжнародних норм у розрахунку на душу населення. У загальному обсязі споживання рисової крупи в країні лише третина припадає на продукцію вітчизняного виробництва. У перспективі, на фоні зростання національної економіки та наближення структури раціону харчування до міжнародних стандартів, попит на крупу рису має підвищитись на 20 тис. т щорічно [1]

Вирощування рису в умовах затоплення можливе лише на рисових зрошувальних системах (Р3С), площа яких в Україні, на нині становить 15 тис. га. Площа щорічних посівів рису не перевищує 11-13 тис. га, середня урожайність знаходиться в межах 5,0-5,5 т/га.

Скорочення вітчизняної пропозиції рису після анекciї АР Крим і втрати 50\% площ побудованих рисових зрошувальних систем змушує проводити пошук напрямів збільшення виробництва продукції цієї культури. Збільшення обсягу виробництва рису можливе за рахунок підвищення ефрективності використання рисових зрошувальних систем або збільшення посівних площ культури. Діючі РЗС в Україні не дозволяють отримати значного підвищення урожайності рису, звідси виникає потреба у збільшенні посівних площ культури. Дослідження 30-х років XX століття підтверджують здатність рослин рису формувати врожай зерна на рівні 4,5-8,7 т/га, на більшій частині території України, від $46^{\circ}$ до $50^{\circ}$ північної широти [2]. Відмова від будівництва дороговартісних рисових зрошувальних систем можлива за впровадження контурних систем та вирощування рису як культури звичайного зрошення.

За рахунок ґрунтових, природно-кліматичних умов та водних ресурсів потенційні площі вирощування рису на півдні України становлять близько 255 тис. га, у тому числі в Херсонській області - 180 тис. га, Миколаївській 35 тис. га, Одеській - 40 тис. га. За насичення рисом сівозмін не більше $50 \%$ валовий збір рису може сягати 850 тис. т, при цьому частка внутрішнього споживання буде становити 20 тис. т, а 600 тис. т може бути експортовано [3].

Аналіз останніх досліджень і публікацій. Виробництво рису у всьому світі пов'язано зі споживанням непропорційно великої кількості прісної води. У глобальному масштабі на зрошуваний рис припадає приблизно 30\% всього забору прісної води (Bouman et. al., 2007), що посилює проблему нестачі води у світі. Очікується, що до 2025 року 15 млн га зрошуваних рисових земель в Азії зазнають «фізичного» дефіциту води, а ще 22 млн га зазнають ії «економічного» дефіциту (Tuongand and Bouman, 2003). Щоб запобігти нестачі води в майбутньому та забезпечити продовольчу безпеку людства, необхідні водозберігаючі альтернативи звичайному затопленому рису.

Однією із перспективних стратегій є вирощування «аеробного рису», який вирощується в незатоплюваних ґрунтових умовах із застосуванням різних систем звичайного зрошення (Boumanand and Tuong, 2001). Аеробний рис, за різними оцінками, може знизити загальне споживання води на $2751 \%$ і підвищити есрективність ії використання на 32-88\% (Bouman et. al., 2005).

Крім вищезазначеної проблеми, вирощування рису у світі в затоплюваних екосистемах створює низку інших проблем, здебільшого екологічного характеру:

- рисові поля є потужним джерелом надходження в атмосферу газу метану, який вважається в 25 разів активнішим агентом впливу на глобальні зміни клімату, ніж діоксид вуглецю;

- у затопленому ґрунті підвищена біодоступність миш'яку (As) спричиняє накопичення цього елементу в рисовій крупі;

- затоплення спричиняє процеси руйнації структури та заболочення ґрунту, підвищення його токсичності та зменшення доступності елементів живлення для рослин рису. 
Ha думку Pinheiro BDS, Castro EDMD, Guimaraes C.M., 2006; Saito K., Linquist B., Atlin G. N., 2006; Wang H., Bouman BAM, Zhao D., Wang C., Moya PF, 2002, більшість із цих проблем можливо вирішити за рахунок широкого впровадження аеробного рису. Аеробний рис - це новий термін, який ввів Міжнародний Науково-дослідний інститут (IRRI), для вирощування високоврожайного рису в незатоплюваних умовах і навіть в не насиченому до 100\% вологості ґрунті, зі збереженням його оптимальних водно-повітряних властивостей. Такі посіви ефективно використовують елементи живлення із застосованих добрив, пристосовані до існування в екосистемі за рахунок природних опадів або зрошення і добре витримують часткове затоплення внаслідок повені. Система була розроблена та прийнята фрермерами більшості традиційних рисосійних регіонів світу.

Подальший розвиток система аеробного рису знайшла в дослідженнях із розроблення технологій вирощування культури в умовах краплинного зрошення в Індії, Китаї, Італії, Японії, Бразилії, США, Австралії та інших країнах. При цьому витрати зрошувальної

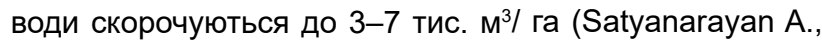
Thiyagarajan T. M., Uphoff N., 2007; Adusumilli N.R., 2014).

Переваги краплинного зрошення перед традиційними способами поливу (дощуванням, поверхневим поливом) відомі давно, і в цьому аспекті варто лише констатувати, що завдяки відповідності технологій краплинного зрошення двом взаємопов'язаним умовам сталого розвитку - високій економічній ефективності та екологічній безпеці, воно набуває широкого застосування для поливу сільськогосподарських культур. За оцінками фахівців, сьогодні у світі зрошують локальними способами поливу понад 10,2 млн га.

Вважається, що урожайність рису в умовах краплинного зрошення або іншого водозберігаючого режиму зрошення нижча, ніж в умовах затоплення, на 10-25\%. Ключовою складовою частиною успіху аеробної рисової системи є вибір або створення відповідних сортів культури, розроблення систем забезпечення елементами живлення та контролю розвитку шкідливих об'єктів [6].

Таким чином, розроблення технології вирощування рису в умовах краплинного зрошення для України $\epsilon$ досить актуальним завданням та перспективним напрямом розвитку галузі рисівництва.

Мета роботи - дослідження особливостей мінерального живлення рослин рису в умовах краплинного зрошення та розроблення ефективної системи мінерального живлення для сучасних сортів рису, яка б забезпечувала реалізацію їх продуктивного потенціалу та забезпечувала би формування високоякісного зерна за відсутності традиційних умов вирощування із затопленням ґрунту.

Матеріали та методика досліджень. Польові дослідження виконувалися упродовж 2016-2019 рр. в ДП ДГ Інституту рису НААН. Дослід було розміщено на території системи краплинного зрошення площею 35 га та на автономному дослідному полігоні площею 4,0 га, в межах закритої зрошувальної системи, побудованої для дощувальних машин ДФ-120 «Дніпро». Водоподача у закриту зрошувальну систему здійснювалася за допомогою насосної станції, яка забезпечує тиск в закритій зрошувальній мережі 74 м та витрати води 560 м³/год. Магістральні трубопроводи діаметром 6 дюймів та розподільчі - діаметром 6 дюймів та 4 дюйми, подають воду у краплинні стрічки, що укладені поверхнево. Проєктний тиск у магістральній мережі - 3 Атм. Для поливу рису використовувалася краплинна стрічка Streamline 16060, мінімальний тиск в емітері 0,4 бар, витрата емітера 0,8-1,1 л/год., відстань між емітерами 0,3 м. Краплинні стрічки розміщували через $0,7 \mathrm{~m}$.

Клімат території помірно-континентальний. Середня тривалість безморозного періоду 224 дні. За роки досліджень максимальна температура повітря за період III декада квітня - III декада вересня коливалася від $20,0{ }^{\circ} \mathrm{C}$ до $39{ }^{\circ} \mathrm{C}$; перепад максимальних значень температури повітря становив $11,0-16,8{ }^{\circ} \mathrm{C}$; мінімальна температура повітря - $1,4-17,8{ }^{\circ} \mathrm{C}$; середньодобова температура повітря - $10,5-18,5{ }^{\circ} \mathrm{C}$, що відрізняється від середньої багаторічної на $0,3-5,7^{\circ} \mathrm{C}$; сума середньодобових температур повітря вище $10^{\circ} \mathrm{C}$ становила $3231,4-3387,2{ }^{\circ} \mathrm{C}$, що є задовільними умовами для росту і розвитку рослин рису. Метеорологічні спостереження, визначення вологості ґрунту на глибині $10 \mathrm{~cm}$, $20 \mathrm{~cm}, 30 \mathrm{~cm}$ проводилися щодня впродовж вегетаційного періоду рису за допомогою метеостанції l-Metos.

Джерело зрошення дослідної ділянки Олександрівський магістральний канал. Зрошувальна вода відповідає I класу якості згідно з ДСТУ 2730:2015, ДСТУ 7591:2014.

Ґрунтовий покрив дослідної ділянки представлено темно-каштановими середньосуглинковими солонцюватими ґрунтами в комплексі з солонцями (30-50\%), $\mathrm{pH}$ (водний) ґрунтового розчину у шарі 0-20 см - 6,38-7,57; вміст гумусу (за Тюріним) - 1,98\%; рухомих фрорм фоосфору (за Мачигіним) - 3,16-3,89 мг / 100 г ґрунту; обмінних фрорм калію (за Мачигіним) - 43,85-45,61 мг / 100 г ґрунту; азоту, що легко гідролізується (за ТюрінимКононовою) - 4,06-5,07 мг / 100 г ґрунту. Тобто ґрунт за відповідними дСТУ характеризується досить високим рівнем родючості та забезпеченості основними елементами живлення.

Як предмет досліджень було використано три сорти рису селекції Інституту рису НААН: Лазуріт - підвид japonica, ранньостиглий (110-115 діб), зернівка подовженої форми, широка (індекс не облущеного зерна 2,8-2,9); Консул - підвид japonica, середньостиглий (120-125 діб), зернівка округлої форми (індекс зерна 2,5-2,6). Маршал - підвид indica, середньостиглий (125-130 діб), довгозерний (індекс зерна 4,3-4,5). Всі сорти мають білу зернівку амілозного типу.

Обробіток ґрунту включав осінню оранку на глибину 20-22 см, вирівнювання довгобазовим планувальником навесні та передпосівну культивацію. Добрива вносили перед сівбою рису у вигляді сульфату амонію або карбаміду та сульфоамофосу; для вегетаційного підживлення способом фертигації використовували карбамід.

Після сівби рису і отримання повних сходів підтримували постійну вологість ґрунту. Вегетаційні поливи розпочинали відразу після сівби, проводили щоденно 
(з перервою під час продуктивних опадів), вологість ґрунту контролювали за допомогою тензіометрів. Вологість шару ґрунту 0-30 см підтримували на рівні 90-100\% НВ. Зрошувана норма за роки досліджень варіювала в межах 10-12 тис. м³.

Результати досліджень. Уже в перший рік проведення досліджень було встановлено, що рис в умовах краплинного зрошення може реалізувати свій генетичний потенціал продуктивності на високому рівні, окремі сорти при цьому формували вищу врожайність зерна порівняно із традиційними умовами вирощування (табл. 1). У перший рік досліджень, коли посіви рису з використанням краплинного зрошення розміщували по незрошуваному попереднику - льону олійному, найбільший врожай зерна рису формувався на досить низькому фоні удобрення $-\mathrm{N}_{50+30} \mathrm{P}_{40}$.

Оптимізація умов мінерального живлення сприяла покращенню технологічних властивостей зерна рису. Так, під час переробки зерна рису, вирощеного в умовах затоплення, максимальний вихід крупи в середньому за три роки досліджень становив 6,9\% у сорту Лазуріт, 73,4\% у сорту Консул та $72,5 \%$ у сорту
Маршал. Максимальний вихід цілого ядра на найбільш сприятливих фонах живлення становив 78,7\%; 94,0\% та 92,8\% відповідно за сортами. Загальний вихід крупи під час переробки зерна рису, вирощеного за умов краплинного зрошення, зростав на 1,1\% у сорту Лазуріт, на $3,9 \%$ у сорту Консул та на $4,3 \%$ у сорту Маршал. Вихід цілого ядра в загальній масі крупи підвищувався на $8,2 \%$ та 1,7\% відповідно у рису сортів Лазуріт і Маршал (табл. 2).

Як було встановлено, покращення технологічних властивостей тісно пов'язано зі змінами в біохімічному складі зернівок. Для проведення аналізу зразки зерна рису було відібрано на варіантах, де вносили мінеральні добрива загальною нормою $\mathrm{N}_{100+40} \mathrm{P}_{40}$. Вміст білка в зерні та крупі рису визначали згідно з ДСТУ 10846-91.

За результатами аналізів встановлено, що в умовах краплинного зрошення, за рахунок оптимізації азотного живлення за фразами вегетації, зростав уміст білка на 2,1-2,38\% в необрушеному зерні та на 2,09-2,25\% у готовій шліфованій крупі (табл. 3).

Підвищений вміст білка, як відомо, придає твердість ендосперму та підвищує його опір під час переробки,

Таблиця 1

Урожайність рису залежно від доз мінерального живлення в умовах краплинного зрошення, т/га

\begin{tabular}{|c|c|c|c|c|c|c|}
\hline \multirow{2}{*}{ Сорт рису (A) } & \multirow{2}{*}{\multicolumn{2}{|c|}{ Дози удобрення (В) }} & \multicolumn{3}{|c|}{ Роки досліджень } & \multirow{2}{*}{ Середнє (B) } \\
\hline & & & 2017 & 2018 & 2019 & \\
\hline \multirow{3}{*}{ Лазуріт } & \multicolumn{2}{|l|}{$\mathrm{N}_{50+30} \mathrm{P}_{40}$} & 7,72 & 5,86 & 5,20 & 6,26 \\
\hline & \multicolumn{2}{|l|}{$\mathrm{N}_{75+30} \mathrm{P}_{40}$} & 7,19 & 6,34 & 5,61 & 6,38 \\
\hline & \multicolumn{2}{|l|}{$\mathrm{N}_{100+30} \mathrm{P}_{40}$} & 7,31 & 6,72 & 6,63 & 6,89 \\
\hline \multirow{3}{*}{ Консул } & \multicolumn{2}{|l|}{$\mathrm{N}_{50+30} \mathrm{P}_{40}$} & 10,15 & 6,59 & 6,07 & 7,61 \\
\hline & \multicolumn{2}{|l|}{$\mathrm{N}_{75+30} \mathrm{P}_{40}$} & 8,71 & 7,29 & 6,62 & 7,54 \\
\hline & \multicolumn{2}{|l|}{$\mathrm{N}_{100+30} \mathrm{P}_{40}$} & 8,52 & 7,68 & 7,20 & 7,80 \\
\hline \multirow{3}{*}{ Маршал } & \multicolumn{2}{|l|}{$\mathrm{N}_{50+30} \mathrm{P}_{40}$} & 10,20 & 6,46 & 5,83 & 7,50 \\
\hline & \multicolumn{2}{|l|}{$\mathrm{N}_{75+30} \mathrm{P}_{40}$} & 9,84 & 7,07 & 6,57 & 7,83 \\
\hline & \multicolumn{2}{|l|}{$\mathrm{N}_{100+30} \mathrm{P}_{40}$} & 9,89 & 7,42 & 7,03 & 8,11 \\
\hline \multirow{2}{*}{\multicolumn{2}{|c|}{$\mathrm{HIP}_{05}$ (для часткових відмінностей) }} & $\mathrm{A}$ & 0,78 & 0,22 & 0,20 & \\
\hline & & $\mathrm{B}$ & 0,47 & 0,21 & 0,21 & \\
\hline \multirow{2}{*}{\multicolumn{2}{|c|}{$\begin{array}{c}\mathrm{HIP}_{05} \text { (для середніх (головних) } \\
\text { ефректів) }\end{array}$}} & $\mathrm{A}$ & 0,45 & 0,13 & 0,12 & \\
\hline & & $\mathrm{B}$ & 0,27 & 0,12 & 0,12 & \\
\hline \multirow{2}{*}{\multicolumn{2}{|c|}{ Частка впливу фракторів,\% }} & A & 77,6 & 42,8 & 28,6 & \\
\hline & & $B$ & 9,2 & 47,6 & 59,5 & \\
\hline
\end{tabular}

Фізичні показники якості та технологічні властивості зерна рису залежно від фону удобрення на краплинному зрошенні (середнє 2017-2019 рр.)

\begin{tabular}{|c|c|c|c|c|c|}
\hline \multirow{2}{*}{ Сорт рису } & $\begin{array}{c}\text { Фон мінераль- } \\
\text { ногоудобрення }\end{array}$ & $\begin{array}{c}\text { Маса } \\
\mathbf{1 0 0 0} \text { зерен, } \mathbf{r}\end{array}$ & Плівчастість, $\%$ & $\begin{array}{c}\text { Загальний вихід крупи, } \\
\text { \% }\end{array}$ & $\begin{array}{c}\text { Вихід цілого ядра, } \\
\text { \% }\end{array}$ \\
\hline \multirow{3}{*}{ Лазуріт } & $\mathrm{N}_{50+30} \mathrm{P}_{40}$ & 24,8 & 25,4 & 69,7 & 80,9 \\
\cline { 2 - 6 } & $\mathrm{N}_{75+30} \mathrm{P}_{40}$ & 23,5 & 24,4 & $\mathbf{7 0 , 5}$ & $\mathbf{8 6 , 9}$ \\
\cline { 2 - 6 } & $\mathrm{N}_{100+30} \mathrm{P}_{40}$ & 22,5 & 23,8 & 69,9 & 82,7 \\
\hline \multirow{3}{*}{ Консул } & $\mathrm{N}_{50+30} \mathrm{P}_{40}$ & 25,6 & 17,9 & 75,5 & 94,2 \\
\cline { 2 - 6 } & $\mathrm{N}_{75+30} \mathrm{P}_{40}$ & 24,4 & 17,6 & $\mathbf{7 7 , 3}$ & 94,0 \\
\cline { 2 - 6 } & $\mathrm{N}_{100+30} \mathrm{P}_{40}$ & 24,4 & 18,0 & 76,3 & 92,5 \\
\hline \multirow{3}{*}{ Маршал } & $\mathrm{N}_{50+30} \mathrm{P}_{40}$ & 25,1 & 18,1 & 75,9 & 90,2 \\
\cline { 2 - 6 } & $\mathrm{N}_{75+30} \mathrm{P}_{40}$ & 25,1 & 18,5 & 76,7 & 92,4 \\
\cline { 2 - 6 } & $\mathrm{N}_{100+30} \mathrm{P}_{40}$ & 25,0 & 18,6 & $\mathbf{7 6 , 8}$ & $\mathbf{9 4 , 5}$ \\
\hline
\end{tabular}


Вміст білка у необрушеному зерні рису та в крупі залежно від умов вирощування культури, \%

\begin{tabular}{|c|c|c|c|c|}
\hline \multirow{2}{*}{ Спосіб зрошення рису (А) } & \multicolumn{3}{|c|}{ Сорт рису (В) } & \multirow{2}{*}{ Середнє по фактору А } \\
\cline { 2 - 5 } & Лазуріт & Консул & Маршал & 7,16 \\
\hline \multicolumn{7}{|c|}{ Рис необлущений (зерно) } \\
\hline затоплення & 8,93 & 6,52 & 6,04 & 9,45 \\
\hline краплинне & 11,03 & 8,90 & 8,41 & 5,57 \\
\hline затоплення & 6,67 & 5,07 & 4,97 & 7,93 \\
\hline краплинне & 8,92 & 7,16 & 7,7 & \\
\hline
\end{tabular}

Таблиця 4

Вміст миш'яку (As) в зерні рису та крупі залежно від умов вирощування культури, мкг/кг

\begin{tabular}{|c|c|c|c|}
\hline Сорт рису & Дози мінеральних добрив & Спосіб зрошення & $\begin{array}{l}\text { Вміст миш'яку } \\
X \pm S_{x}\end{array}$ \\
\hline \multicolumn{4}{|c|}{ Зерно рису } \\
\hline \multirow{4}{*}{ Віконт } & \multirow{2}{*}{$\mathrm{N}_{120} \mathrm{P}_{40}$} & затоплення & $393,5 \pm 1,4$ \\
\hline & & краплинне & $106,5 \pm 9,0$ \\
\hline & \multirow{2}{*}{$\mathrm{N}_{180} \mathrm{P}_{40}$} & затоплення & $310,2 \pm 8,1$ \\
\hline & & краплинне & $76,0 \pm 12,7$ \\
\hline \multirow{2}{*}{ Консул } & \multirow{2}{*}{$\mathrm{N}_{180} \mathrm{P}_{40}$} & затоплення & $271,3 \pm 7,3$ \\
\hline & & краплинне & $87,2 \pm 10,7$ \\
\hline \multicolumn{4}{|c|}{ Крупа рису } \\
\hline \multirow{2}{*}{ Віконт } & \multirow{2}{*}{$\mathrm{N}_{180} \mathrm{P}_{40}$} & затоплення & $221,8 \pm 4,9$ \\
\hline & & краплинне & $23,6 \pm 4,2$ \\
\hline
\end{tabular}

що сприяє покращенню технологічних властивостей зерна та підвищує його поживну цінність.

Відомо, що в умовах затоплення підвищена біологічна доступність миш'яку є основною причиною накопичення цього токсичного елемента в зерні рису (Fitz W.J. and Wenzel W.W., 2008).

Згідно з даними наших досліджень було встановлено, що за краплинного зрошення вміст миш'яку в зерні рису сортів Віконт та Консул зменшувався більш ніж у три рази порівняно із затоплюваним рисом (табл. 4).

У крупі рису, вирощеного в екосистемі краплинного зрошення, токсичного елементу визначалося майже в 10 разів менше порівняно із рисом, вирощеним у затоплених умовах за традиційною технологією. Таким чином, впровадження технології вирощування рису на краплинному зрошенні дає можливість отримувати екологічно безпечну продукцію з підвищеними поживними якостями.

Але при всіх позитивних результатах проведених досліджень було виявлено певні негативні моменти. Використання дільниці під краплинне зрошення рису (2018-2019 рр.) після таких попередників, як кукурудза та соя, зрошення яких здійснювалося цим же способом, з роками потребувало збільшення витрат на мінеральні добрива для отримання врожаю. Так, якщо на початку досліджень більша частка впливу на рівень урожаю зерна в загальній дії факторів - 77,6\% - припадала на сортові (генетичні) особливості культури, тоді як частка впливу фону мінерального живлення не перевищувала 9,2\%. 3 роками це співвідношення змінювалося, збільшення врожайності можна було досягнути лише за внесення підвищених доз мінеральних добрив. При цьому урожайність рису загалом зменшувалася на 14,1-31,1\% на дільниці, де краплинне зрошення використовували 5 років, порівняно із дільницею, де рис на зрошенні висівали вперше (рис. 1).

Аналіз отриманих результатів показав, що в середньому за три роки досліджень вирощування рису сорту Лазуріт в умовах краплинного зрошення було збитковим. Рівень рентабельності вирощування та переробки зерна рису сортів Консул і Маршал в середньому за роки досліджень становив 22,1-33,2\%. Кращі результати отримано на варіанті, де вносили високі норми мінеральних добрив, зокрема азотних.

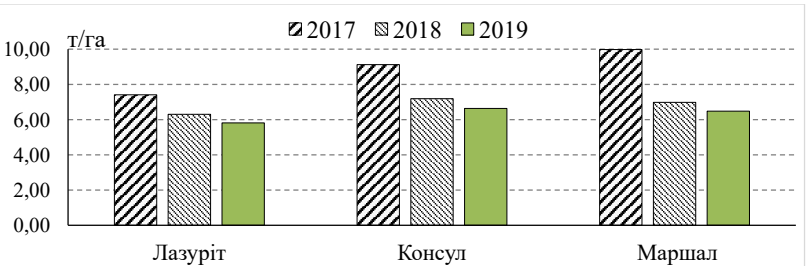

Рис. 1. Середній рівень урожайності зерна рису трьох сортів в умовах краплинного зрошення за роками досліджень

За роками досліджень спостерігалася негативна динаміка показників економічної ефективності, у прямій залежності від зменшення продуктивності культури за зростання виробничих витрат (рис. 2). Вирощування рису в умовах краплинного зрошення найбільш пристосованих сортів - Маршал та Консул - мало хоча й не високий, але позитивний економічний ефект. 


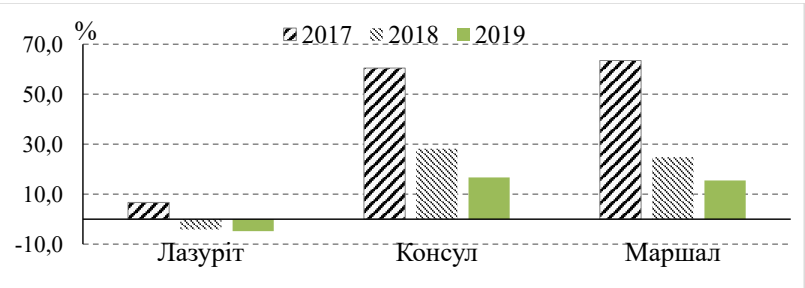

Рис. 2. Рівень рентабельності вирощування сучасних сортів рису з урахуванням фактичної врожайності зерна та його технологічних властивостей в умовах краплинного зрошення

Детальний аналіз причин зниження врожаю дає змогу припустити, що причини криються в такому:

- недосконала система захисту від бур'янів (шар води в умовах рисових зрошувальних умов $\epsilon$ стримуючим фрактором проростання та сходів бур'янів роду Echinochloa). Багаторазове застосування гербіцидів не гарантує високої ефективності, водночас проявляється певна фітотоксичність щодо рослин рису. Виникає необхідність створення сортів із підвищеною конкурентоздатністю щодо бур'янів, особливо на початкових етапах росту і розвитку рослин рису;

- погіршення агромеліоративних умов дослідної дільниці на певних етапах ії використання потребує досліджень із добору та створення сортів рису, стійких до підвищеної концентрації солей в кореневмісному шарі ґрунту [5];

- відсутність сортів рису, які б ефективно реагували на аеробні ґрунтові умови і мали б генетично змодельовані певний рівень посухостійкості та здатність використовувати елементи живлення з незатопленого ґрунту [6];

- відсутність системи знань з ефективної системи спеціалізованих рисових сівозмін в умовах краплинного зрошення.

Висновки. Впровадження технології вирощування рису на краплинному зрошенні - це реальна можливість збільшити площі посіву рису в Україні, підвищити обсяги власного виробництва продукції рисівництва та зменшити імпортозалежність. Встановлено, що за вирощування на краплинному зрошенні рису можливе отримання високого рівня врожаю за суттєвого зменшення виробничих витрат:

- економія води для зрошення з 24-25 тис. м³/га до 10-12 тис. $\mathbf{M}^{3} /$ га;

- зменшення норми висіву в два рази та витрат на дороговартісний посівний матеріал за рахунок високої польової схожості насіння;

- зменшення доз мінеральних добрив, зокрема азотних, за рахунок відсутності промивного водного режиму та непродуктивних втрат елементів живлення, а також можливості регулярних підживлень способом фертигації в найбільш чутливі фази росту та розвитку і підвищення за рахунок цього коефіцієнтів їх засвоєння рослинами рису.

Встановлено, що оптимізація умов мінерального живлення рослин рису за краплинного зрошення сприяла покращенню якості зерна рису - як технологічних властивостей, так і біохімічного складу:
- загальний вихід крупи під час переробки зерна рису зростав на 1,1\% у сорту Лазуріт, на 3,9\% у сорту Консул та на 4,3\% у сорту Маршал. Вихід цілого ядра в загальній масі крупи підвищувався на $8,2 \%$ та 1,7\% відповідно у рису сортів Лазуріт і Маршал;

- зростав уміст білка на 2,1-2,38\% в необрушеному зерні рису та на 2,09-2,25\% у готовій шліфованій крупі, що позитивно впливає на поживні якості продукції;

- вміст миш'яку в зерні рису сортів Віконт та Консул зменшувався більш ніж у три рази, а у шліфованій крупі майже в 10 разів порівняно із затоплюваним рисом, що дозволяє підвищити статус екологічної безпечності продукції рисівництва

\section{СПИСОК ВИКОРИСТАНОÏ ЛІТЕРАТУРИ:}

1. Дудченко В.В. Державне законодавче регулювання рисового виробництва та його наукове забезпечення в Україні / ред. В.А. Вергунова. Херсон: Айлант, 2015. $60 \mathrm{c}$.

2. Технологія вирощування рису з врахуванням вимог охорони навколишнього середовища в господарствах України / Дудченко В.В. та ін. Херсон: вид-во «Наддніпряночка», 2008. 71 с.

3. Технологія вирощування рису на краплинному зрошенні в Україні / В.В. Дудченко та ін. Херсон: Грінь Д.С., 2016. 32 с.

4. Adusumilli N.R. Drip irrigation system for higher resources use efficient rice production with reduced global warming potential - a review. 4th International Rice Congress 27 Oct. 1 Nov. Bangkok, Thailand. 2014.

5. Bennett J., Khush G.S. A strategy for enhancing salt tolerance in crops through molecular breeding. J. Crop Prod. 2002. № 7. (In press.)

6. Bouman B.A.M., Hengsdijk H., Hardy B., Bindraban P.S., Tuong T.P., Ladha J.K. Water-wise rice production. Proceedings of the International Workshop on Waterwise Rice Production, 8-11 April 2002, Los Banos, Philippines. Los Banos (Philippines): International Rice Research Institute. 356 p.

7. Bouman B.A.M., Humphreys E., Tuong T. P., Barker R. Rice and water. Adv. Argon. 2007; 92:187-237. doi: 10.1016/S0065-2113(04)92004-4.

8. Bouman B.A.M., Peng S., Castaneda A., Visperas R.M. Yield and water use of irrigated tropical aerobic rice systems. Agric. Water Manage. 2005; 74:87-105. doi: 10.1016/j.agwat.2004.11.007.

9. Bouman B.A.M., Tuong T.P. Field water management to save water and increase its productivity in irrigated rice. Agric. Water Manage, 2001; 49:11-30. doi: 10.1016/ S0378-3774(00)00128-1.

10. Bozkurt Çolak Y. Comparison of aerobic rice cultivation using drip systems with conventional flooding. The Journal of Agricultural Science, 2021; 11.1017/ S0021859621000824, (1-13).

11. Fitz W.J., Wenzel W.W. Arsenic transformation in the soil-rhizosphere-plant system: fundamentals and potential application to phytoremediation. J. Biotechnol. 2002; 99: 259-278.

12. Pinheiro B.D.S., Castro E.D. M.D., Guimaraes C.M. Sustainability and profitability of aerobic rice production in Brazil. Field Crops Res, 2006; 97:34-42. doi: 10.1016/j.fcr.2005.08.013. 
13. Saito K., Linquist B., Atlin G.N. Response of traditional and improved rice cultivars to $\mathrm{N}$ and $\mathrm{P}$ fertilizer in northern Laos. Field Crops Res, 2006; 96:216-223. doi: 10.1016/j.fcr.2005.07.003.

14. Satyanarayan A., Thiyagarajan T.M., Uphoff N. Opportunities for water saving with higher yield from the system of rice intensification. Irrigation Science, 2007. № 25. pp. 99-115.

15. Tuong T.P., Bouman B.A.M. Rice production in waterscarce environments, In: Proc. Water Productivity Workshop, 12-14 November 2001, Colombo, Sri Lanka. International Water Management Institute, Colombo, Sri Lanka, 2003.

\section{REFERENCES:}

1. Dudchenko, V.V. (2015). Derzhavne zakonodavche regulyuvannya risovogo virobnictva ta jogo naukove zabezpechennya $v$ Ukraini [State legislative regulation of rice production and its scientific support in Ukraine]. Kherson: Ajlant [in Ukrainian].

2. Dudchenko, V.V. et al. (2008). Tekhnologiya viroshchuvannya risu z vrahuvannyam vimog ohoroni navkolishn'ogo seredovishcha $v$ gospodarstvah Ukraïni [Technology of rice cultivation taking into account the requirements of environmental protection in the farms of Ukraine]. Kherson: vid-vo «Naddnipryanochka» [in Ukrainian].

3. Dudchenko, V.V., Kornberher, V.H., \& Marushchak, H.M. et al. (2016). Tekhnolohiia vyroshchuvannia rysu na kraplynnomu zroshenni v Ukraini [Technology of rice cultivation on drip irrigation in Ukraine]. Kherson: Hrin D.S. [in Ukrainian].

4. Adusumilli, N.R. (2014). Drip irrigation system for higher resources use efficient rice production with reduced global warming potential - a review.4th International Rice Congress 27 Oct. 1 Nov. Bangkok, Thailand

5. Bennett, J., \& Khush, G.S. (2002). A strategy for enhancing salt tolerance in crop through molecular breeding. $J$. Crop Prod. №7. (Inpress.)

6. Bouman B.A.M., Hengsdijk H., Hardy B., Bindraban P.S., Tuong T.P., \& Ladha J.K. (Eds). Water-wiser rice production. Proceedings of the International Workshop on Water-wise Rice Production, 8-11 April 2002, Los Banos, Philippines. Los Banos (Philippines): International Rice Research Institute. pp. 356.

7. Bouman, B.A.M., Humphreys, E., Tuong, T.P., \& Barker, R. (2007). Rice and water. Adv. Argon, 92, 187-237. doi:10.1016/S0065-2113(04)92004-4

8. Bouman, B.A.M., Peng, S., Castaneda, A., \& Visperas, R.M. (2005). Yield and water use of irrigated tropical aerobic rice systems. Agric. Water Manage, 74, 87-105. doi: 10.1016/j.agwat.2004.11.007

9. Bouman, B.A.M., \& Tuong, T.P. (2001). Field water management to save water and increase its productivity in irrigated rice. Agric. Water Manage, 49, 11-30. doi:10.1016/S0378-3774(00)00128-1

10. Bozkurt, Çolak Y. (2021). Comparis on of aerobic rice cultivation using drip systems with conventional flooding. The Journal of Agricultural Science, 1017/ S0021859621000824, pp. 1-13

11. Fitz, W.J., \& Wenzel, W.W. (2002). Arsenic transformation in the soil-rhizosphere-plant system: fundamentals and potential application to phytoremediation. J. Biotechnol, 99, 259-278
12. Pinheiro, B.D.S., Castro, E.D.M.D., \& Guimaraes, C.M. (2006). Sustainability and profitability of aerobic rice production in Brazil. Field Crops Res, 97, 34-42. doi: 10.1016/j.fcr.2005.08.013

13. Saito, K., Linquist, B., \& Atlin, G.N. (2006). Response of traditional and improved rice cultivars to $\mathrm{N}$ and $\mathrm{P}$ fertilizer in northern Laos. Field Crops Res, 96, 216-223. doi: 10.1016/j.fcr.2005.07.003

14. Satyanarayan, A., Thiyagarajan, T.M., \& Uphoff, N. (2007). Opportunities for water saving with higher yield from the system of rice intensification. Irrigation Science, № 25, 99-115.

15. Tuong, T.P., \& Bouman, B.A.M. (2003). Rice production in water-scarce environments, In: Proc. Water Productivity Workshop, 12-14 November 2001, Colombo, Sri Lanka. International Water Management Institute, Colombo, Sri Lanka

Воронюк 3.С., Вожегов С.Г., Ткач М.С., Роменський В.Ю. Урожайність та якість зерна рису в умовах краплинного зрошення залежно від доз мінеральних добрив

Одним із напрямів розвитку галузі рисівництва в Україні $€$ впровадження технологій вирощування культури поза межами рисових зрошувальних систем із використанням можливостей краплинного зрошення. Мета роботи - дослідження особливостей мінерального живлення рослин рису в умовах краплинного зрошення та розроблення ефективної системи мінерального живлення для сучасних сортів рису, яка б забезпечувала реалізацію їх продуктивного потенціалу та забезпечувала би фрормування високоякісного зерна. Методи. Польові дослідження виконувалися упродовж 2016-2019 рр. в ДП ДГ Інституту рису НАAН на полігоні краплинного зрошення. Застосовані методи - польовий із супутніми спостереженнями і аналізами, лабораторний, математично-статистичний та теоретично-узагальнюючій. Результати. Урожайність трьох сортів рису, що вивчалися у досліді, варіювала в досить широких межах від 5,2 т/га у 2019 році у сорту Лазуріт до 10,2 т/га у сортів Консул і Маршал у 20017 році. У середньому за три роки досліджень максимальну урожайність зерна - 6,89 т/га у сорту Лазуріт; 7,80 т/га у сорту Консул та 8,11 т/га у сорту Маршал - отримано при внесенні $100 \mathrm{kr/га} \mathrm{азоту,} 40$ кг/га фоссфору перед сівбою та 30 кг/га азоту за діючою речовиною у підживлення способом фертигації. При цьому у всіх сортів рису покращувалися технологічні властивості - вихід крупи збільшувався на 1,1-4,3\%, а вихід цілого ядра на $1,7-8,2 \%$. Покращення умов азотного живлення сприяло підвищенню вмісту білка в зерні на 2,1-2,4\%. Вміст миш'яку в зерні рису зменшувався більш ніж у три рази, порівняно із затоплюваним рисом, що дозволяє підвищити статус екологічної безпечності продукції рисівництва. Висновки. В умовах краплинного зрошення, за створення сприятливих умов росту і розвитку, зокрема застосування ефективної системи живлення, рис реалізує свій потенціал продуктивності на досить високому рівні. Найбільш пристосованими до умов вирощування без постійного затоплення є середньостиглі сорти рису Консул і Маршал.

Ключові слова: зрошення, рис, сорт, добрива, ефективність, технологічні властивості, біохімічний склад. 
Voronyuk Z.S., Vozhehov S.G., Tkach M.S., Romensky V.Yu. Yield and quality of rice grain in the conditions of drip irrigation depending on doses of mineral fertilizers

One of the directions of the rice industry development in Ukraine is the introduction of technologies for growing crops outside the rice irrigation systems using the possibilities of drip irrigation. The aim of the work is to study the features of mineral nutrition of rice plants under drip irrigation and to develop an effective system of mineral nutrition for modern rice varieties, which would ensure the realization of their productive potential and ensure the formation of high quality grain. Methods. Field research was carried out during 2016-2019 in the SE of the Rice Institute of NAAS at the drip irrigation landfill. The applied methods are field with accompanying observations and analyzes, laboratory, mathematicalstatistical and theoretical-generalizing. Results. Yields of three rice varieties studied in the experiment varied quite widely from $5.2 \mathrm{t} /$ ha in 2019 in Lazurite variety $10.2 \mathrm{t} /$ ha in the varieties Consul and Marshall in 2017. On average, for three years of research, the maximum grain yield is $6.89 \mathrm{t} /$ ha in the Lazurite variety; $7.80 \mathrm{t} / \mathrm{ha}$ in the Consul variety and $8.11 \mathrm{t} /$ ha in the Marshall variety were obtained by applying $100 \mathrm{~kg} /$ ha of nitrogen, $40 \mathrm{~kg} / \mathrm{ha}$ of phosphorus before sowing and $30 \mathrm{~kg} / \mathrm{ha}$ of nitrogen for the active substance in fertilization by fertigation. At the same time, all rice varieties improved their technological properties the yield of cereals increased by $1.1-4.3 \%$, and the yield of whole kernels by $1.7-8.2 \%$. The improvement of nitrogen nutrition conditions helped to increase the protein content of grain by $2.1-2.4 \%$. The arsenic content of rice grain decreased more than three times compared to flooded rice, which increases the environmental safety status of rice products. Conclusions. Under the conditions of drip irrigation, for the creation of favorable conditions for growth and development, in particular the use of an efficient food system, rice realizes its productivity potential at a high level. Medium-ripe rice varieties Consul and Marshall are the most suitable for growing conditions without constant flooding.

Key words: irrigation, rice, variety, fertilizers, efficiency, technological properties, biochemical composition. 